\title{
Floating around in the Dutch nominal domain
}

\author{
Norbert Corver \\ Utrecht University
}

In this article I investigate the internal syntax of Dutch nominal expressions like twee slangen van elk twee meter (two snakes of each two meter). The preposition van separates the quantifier elk from the expression twee slangen to which it is connected interpretatively. From a purely observational view, the quantifier could be said to be floating in the nominal domain. In this article I argue that this floating elk is an instance of so-called 'binominal each'. So far, discussions of the binominal-each-phenomenon have concentrated on dependencies involving material in the clausal domain. In this article I show that dependencies involving binominal elk are also attested DP-internally. Syntactic issues that will be discussed in the context of the DP-internal binominal-each-phenomenon include: Constituency of the nominal expression, the nature of the DP-internal anaphoric dependency, the various manifestations of the binominal pattern, and word order rearrangements by DP-internal displacement.

Keywords: Cross-categorial symmetry, floating quantifier, binominal each, nominal expression

\section{Introduction}

An important research strategy in generative linguistics is the quest for symmetry. A phenomenon that exists in one syntactic domain (e.g. the clause) arguably also exists in another syntactic domain (e.g. the nominal domain). For example, passivization, as in Carthago was destroyed by the Romans, is familiar from the clausal domain and has been shown to exist in the nominal domain (Carthago's destruction by the Romans). In line with the quest for cross-categorial symmetry, I will address in this article the question as to whether the phenomenon of quantifier floating, quite familiar from the clausal domain, is also attested in the nominal domain, and if so, what the analysis of this floating quantifier should be. Importantly, at this point I use the notion of 'quantifier floating' in a theory-neutral way, in the 
sense that it refers to a pattern in which, at the surface, a quantifier is separated from the nominal element that it is interpretatively connected with.

The article is organized as follows: Section 2 introduces the nominal pattern in Dutch featuring the floating quantifier. It will be shown that this pattern does not instantiate the phenomenon of Quantifier-float (Q-float) but rather the socalled Binominal-each-phenomenon (BIN-each). Section 3 discusses the internal syntax of the noun phrase-internal BIN-each-phenomenon and Section 4 some of the semantic restrictions on this construction. In Section 5 it is shown that the dependency between the quantifier and the antecedent displays the same properties as those found in dependencies between a bound anaphor and its antecedent. Section 6 shows that the DP-internal 'binominal each' phenomenon manifests itself in different guises, and Section 7 briefly discusses patterns of word order variation. Section 8 is the conclusion.

\section{Noun phrase internal floating}

Consider the bracketed nominal expressions in (1):

(1) a. Jan en Marie zagen [twee slangen van elk twee meter]

Jan and Marie saw two snakes of each two meter

b. Jan en Marie kochten [twee flinke kippenbouten van elk 250 gram] Jan and Marie bought two large chicken-breasts of each 250 gram

The bracketed nominal expressions display a discontinuous dependency between a quantifier (elk) and its antecedent (twee slangen/twee flinke kippenbouten). Specifically, the prepositional element van intervenes between the antecedent and the quantifier. So we have the floated usage of elk in the sense that it is separated from the antecedent to which it is connected interpretatively.

The question arises as to what mechanism underlies this discontinuous relationship. In the literature, two types of constructions displaying such a discontinuity with a quantifier have been identified: (a) the Q-float construction (cf. Sportiche 1988; Doetjes 1997; Bobaljik 2003; Cirillo 2009) and (b) the binominal/adnominal each-construction (Burzio 1986; Safir \& Stowell 1988; Zimmerman 2002; Blaheta 2003). The first construction is exemplified in (2a), the second one in (2b).

$\begin{array}{lll}\text { (2) a. The men have }[V P \text { each } & \left.\left.{ }_{V P} \text { seen two women }\right]\right] & \text { (Q-float each) } \\ \text { b. The men have seen }[D P & \text { two women each }] & \text { (binominal each) }\end{array}$

In both examples, the quantifier each is distant from its antecedent, the subject the men. However, they differ from each other in the placement of the quantifier. In (2a), each is located in a clause-internal position (here represented as adjunction 
to VP) whereas in (2b) each is located inside a DP. This DP-internal placement of binominal each is clear from the fact that it moves along with the rest of the direct object when the latter undergoes movement, as in How many women each did the men see? (Compare: ${ }^{\star}$ How many women did the men see each?) and Two women each were seen by the men (Compare: ${ }^{\star}$ Two women were seen each by the men); see Burzio (1986).

Taking the two construction types in (2) as our background, let us try to find out whether the bracketed nominal expressions in (1) display Q-float each or binominal each. I will start with the Q-float option. Roughly, two approaches towards Q-float can be identified in the literature: (a) the adverbial analysis (Doetjes 1997), according to which the quantifier is base-generated as an adjunct and separate from the antecedent (see (2a)); (b) the movement analysis, according to which the quantifier and the antecedent start out as a unit and get separated as a result of movement of the antecedent (Sportiche 1988). According to the movement analysis, the sentence The men have each seen two women has the derived structure in (3):

(3) The men ${ }_{i}$ have $\left[_{V P}\left[_{D P} t_{i}\right.\right.$ each $]\left[_{V}\right.$ seen two women $\left.]\right]$

Let us first explore an analysis according to which the bracketed nominal expressions in (1) involve movement of the antecedent (e.g. twee slangen) away from the quantifier elk. Building on Kayne (1994: Chapter 8), for example, one could hypothesize that twee slangen originates as a DP-internal small clause subject and raises to the Spec-position of the prepositional D van.

(4) $\left[_{D / P P}[\text { twee slangen }]_{i}\left[_{D}\right.\right.$, van $\left[_{I P}\left[\right.\right.$ elk $\left.t_{i}\right]\left[_{I}, I[2\right.$ meter $\left.\left.\left.\left.]\right]\right]\right]\right]$

This movement analysis of DP-internal floating elk faces an important problem. The quantifier elk can also be stranded within an adjunct-PP (see (5a)) or a conjunct of a coordinate structure (see (5b)). Since these are canonical island-configurations, a movement analysis in which the quantifier is stranded as result of displacement of the antecedent is implausible.

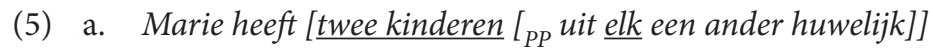
Marie has two children from each a different marriage

b. twee adoptiekinderen $\left[_{\text {Conjp }}\right.$ [van tien jaar] en [met elk een eigen levensgeschiedenis]] two adoption-children of ten years and with each an own life-history

What about an adverbial Q-floating analysis of the patterns in (1), analogously to the clause-internal Q-floating structure in (2a)? Such an analysis is unlikely for two reasons. First, it has been observed in the literature that in many languages the quantifier displays agreement with the antecedent in Q-float environments. For example, as Zimmermann (2002: 29-30) points out for German, the quantifier 
jeder displays phi-feature agreement with the antecedent (see (6a)). He further observes that this agreement pattern is impossible with floating quantifiers in the nominal domain (see (6b)). Zimmermann notes that the (non-agreeing) quantifier jeweils 'each', which he analyzes as an instance of binominal each, does occur in both nominal and clausal environments; see (7). On the basis of the impossibility of (6b), Zimmerman concludes that the phenomenon of Q-float is not attested in the German noun phrase.

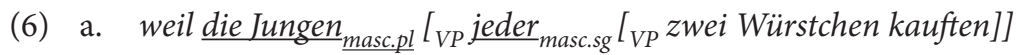
because the boys each two sausages bought

b. * [Die Mütter fem.pl $_{\text {. }}\left[\right.$ von jede $e_{\text {fem.sg }}$ zwei Söhnen]] wurden geehrt. the mothers of each two sons were honored

(7) a. weil die Jungen $\left[_{D P}\right.$ jeweils zwei Würstchen] kauften because the boys each two sausages bought

b. [Die Mütter [von jeweils zwei Söhnen]] wurden geehrt. the mothers of each two sons were honored

Another and related argument against treating elk in (1) as a true instance of Q-float comes from the fact that not all quantifiers that we find in Q-float contexts in the clausal domain are possible in the nominal domain. For example, Dutch allemaal and allen 'all' are allowed as floating quantifiers in the clausal domain but not in the nominal domain.

(8) a. Deze drie slangen zijn volgens mij elk/allemaal 3 meter lang. these three snakes are according-to me each/all 3 meter long

b. [Deze drie slangen van elk/*allemaal 3 meter] zijn zeldzaam. these three snakes of each/all 3 meter are rare

(9) a. Deze drie kinderen zijn elk/allen 15 jaar oud. these three children are each/all human.pl $_{15}$ year old

b. [Deze drie kinderen van elk/*allen 15 jaar oud] zitten bij mij in these three children of each/all human.pl $_{15}$ year old sit with me in de klas

the classroom

On the basis of the above-mentioned problems that a Q-float interpretation of the patterns in (1) is faced with (i.e. both the movement approach and the adverbial approach), I conclude that these DP-internal floating quantifiers are actually instances of binominal each (compare (2b)). This means that the quantifier is basegenerated as a subconstituent of a noun phrase. Following Safir \& Stowell (1988), I will call the nominal constituent twee slangen in (1a) the Range-NP and the nominal constituent twee meter the Dist(ributing)-NP. 
(10) $\underline{\text { twee slangen }}_{\underline{\text { Range-NP }}}$ van elk twee meter $\underline{\text { Distributing-NP }}$

The Dist-NP represents the thing or property being distributed across multiple individuals/entities. The Range-NP represents the group being distributed over.

\section{The internal syntax of the nominal 'binominal each'-construction}

Having determined that the patterns in (1) involve binominal elk, let us briefly consider the internal syntax of these patterns. First of all, it can be observed that the sequence van+elk+Dist-NP is part of a larger noun phrase. Evidence for this comes from the fact that this sequence moves along with the rest of the noun phrase (the Range-NP) when this part is fronted.

(11) a. Jan heeft [twee schilderijen van elk 50 euro] gekocht Jan has two paintings of each 50 euro bought

b. [Hoeveel schilderijen van elk 50 euro] ${ }_{i}$ heeft Jan $t_{i}$ gekocht? how-many pictures of each 50 euro has Jan bought

Second, it can easily be shown that the sequence van+elk+Dist-NP forms a constituent (PP). For example, it can undergo extraposition (12a) and it can form a conjunct in a coordination structure (12b).

(12) a. Jan heeft $\left[_{D P} \text { twee schilderijen } t_{i}\right]_{\text {gekocht }}\left[_{P P} \text { van elk } 50 \text { euro }\right]_{i}$ Jan has two paintings bought of each 50 euro

b. [Twee vluchten $\left[_{\text {Conjp }}\left[_{P P}\right.\right.$ van elk 10 uur] en $\left[_{P P}\right.$ met elk een andere bestemming]]] waren gecanceld

Two flights of each 10 hours and with each a different destination were canceled.

Third, the sequence elk+Range-NP forms a constituent. Evidence for this comes from coordination patterns like (13). This example shows that the binominal quantifier can be part of a conjunct of a coordinate structure. A sequence of elements that can function as a conjunct is generally taken to form a constituent.

(13) twee kranen [ ${ }_{P P}$ van [Conjp [elk 80 meter hoog] en [elk $\left.\left.\left.800.000 \mathrm{~kg} z w a a r\right]\right]\right]$ two cranes of each 80 meter high and each $800.000 \mathrm{~kg}$ heavy

Finally, I assume that the PP in which binominal elk is embedded is adjoined to NP or NumP. Evidence for this comes from er-pronominalization patterns (Bennis 1986). The PP can but need not be part of the pronominalized form (see (14a) versus (14b)). Under the assumption that er pronominalizes a phrasal constituent (XP), PP is adjoined to NP in (14a) and to NumP in (14b). 
(14) Jan heeft gisteren $\left[_{D P}\right.$ twee schilderijen van elk 50 euro] gekocht en ... Jan has yesterday two paintings of each 50 euro bought and ...

a. Piet heeft er ${ }_{i}$ toen $\left[_{D P}\right.$ drie $\left.t_{i}\right]$ gekocht.

Piet has there ( $=$ of them) then three - bought

b. Piet heeft er ${ }_{i}$ toen $I_{D P}$ drie $t_{i}$ van elk 100 euro] gekocht.

Piet has there ( $=$ of them) then three - of each 100 euro bought

On the basis of the above observations I conclude that the nominal expression in (1a) has the following internal syntax (with adjunction here to NumP):

$$
\left.\left[_{D P} D\left[_{\text {NumP }}\left[{ }_{\text {NumP }} \text { twee }\left[_{N P} \text { slangen }\right]\right]\left[_{P P} \text { van [elk twee meter }\right]\right]\right]\right]
$$

\section{Semantic restrictions on the Dist-NP and the Range-NP}

If the nominal expressions in (1) feature a binominal quantifier (in casu elk), we expect this expression to display the same semantic restrictions as the ones found in the clausal domain. As Safir \& Stowell (1988: 428) have observed for English, the Dist-NP must be cardinal and indefinite (see (16a)). Definite NPs and quantified plural NPs are all excluded (see (16b)). As shown in (17) for Dutch, the same interpretive restrictions hold for noun phrase internal Dist-NPs.

(16) a. The men saw [ [one jewel/two jewels/several jewels] each]

b. ${ }^{*}$ The man saw [ [the/those/some/all jewels] each]

(17) a. twee sanitaire ruimtes met elk één douche/twee douches/verscheidene douches

two sanitary locations with each one shower/two showers/several showers

b. * twee sanitaire ruimtes met elk de/die/sommige/alle douches two sanitary locations with each the/these/some/all showers

As for the Range-NP, Safir \& Stowell (1988: 428) observe that it must be plural (see $(18 \mathrm{a}, \mathrm{b})$ ). As shown by the Dutch examples in (19), the same restriction holds for the Range-NP in the noun phrase internal binominal construction.

(18) a. They / [the/those/some/several men] saw two women each

b. ${ }^{*}$ She $/{ }^{*}$ Joe $/ *[$ the $/$ a/no man $]$ saw two women each

(19) a. ${ }^{*}$ een/de sanitaire ruimte ${ }_{\mathrm{sg}}$ met elk drie douches a/the sanitary location with each three showers

b. de/deze/verschillende sanitaire ruimtes ${ }_{\mathrm{pl}}$ met elk drie douches the/these/several sanitary locations with each three showers 
In sum, we find the same semantic restrictions on the Range-NP and the Dist-NP in the noun phrase internal binominal pattern as in the clause internal binominal pattern.

\section{DP-internal binominal elk 'each': an anaphoric dependency}

So far, I have tried to show that the bracketed nominal expressions in (1) are constructions featuring a binominal quantifier elk. This binominal element is attached to the Dist-NP and together they are in the complement position of a preposition. In this section, I will address the following question: What is the nature of the dependency between binominal elk and the Range-NP? In the spirit of what Burzio (1986) has proposed for binominal each in the clausal domain, I will argue and show that noun phrase-internal binominal elk also enters into a bound-anaphoric dependency with an antecedent. As will become clear below, (DP-internal) binominal elk displays a variety of properties that are characteristic of bound anaphors.

First of all, there is the obligatoriness of the antecedent (Range-NP). More specifically, the Range-NP has to be expressed by a plural expression that denotes a group or set of individuals. In (20a), twee halters functions as the plural antecedent for elk. In (20b), no plural expression is available that can function as the antecedent for elk. As a result of that, this example is ill-formed.

(20) a. Jan tilde [twee halters van elk 75 kilo] op.

Jan lifted two dumbbells of each 75 kilo PRT

b. ${ }^{\star}$ Jan tilde [een halter van elk 75 kilo] op.

Jan lifted a dumbbell of each 75 kilo PRT

Secondly, there must be a unique antecedent (i.e. Range-NP) for the binominal quantifier. It is not possible to have two separate Range-NPs that enter into a dependency with a single Dist-NP; see (21a). So, uniqueness applies to the RangeNP. Notice that when the two NPs are coordinated and consequently form a single antecedent, the nominal expression is fine. Note in passing that a single Range-NP can enter into a relationship with more than one Dist-NP; see (22).

(21) a. *een vertaling ${ }_{i}$ van een gedicht $_{j}$ [van elk ${ }_{i+j}$ honderd woorden] a translation of a poem of each hundred words

b. [een gedicht $t_{i}$ en een vertaling ${ }_{j}$ [ [van elk , $_{i+j}$ honderd woorden] a poem and a translation of each hundred words

(22) twee busritten [van elk 16 uur] [naar elk een andere bestemming] two bus-rides of each 16 hour to each a different destination 
Thirdly, the antecedent (Range-NP) must be structurally more prominent than the binominal quantifier. More specifically, the Range-NP must c-command the quantifier. This structural requirement is exemplified in (23). In (23a), the modifying PP van elk drie millimeter is adjoined to the nominal constituent (more specifically, NumP) twee wratten. I assume that the lower NumP-segment c-commands the adjoined PP. In (23b), however, the modifying PP van elk drie minuten belongs to the matrix NP headed by behandeling. In this structure twee wratten is too deeply embedded for being able to license (c-command) the binominal quantifier.

(23) a. [een behandeling [van [twee wratten [van elk drie millimeter]]]] a treatment of two warts of each three millimeter

b. * [een [[behandeling [van twee wratten]] [van elk drie minuten]]] a treatment of two warts of each three minutes

A further illustration of the importance of c-command comes from the following minimal pair. In (24a), the Range-NP twee moeders has c-command over the DistNP elk drie kinderen. In the ill-formed example (24b), the relationship is reversed within the complex noun phrase: The Dist-NP elk twee moeders is structurally more prominent than the Dist-NP drie kinderen.

(24) a. Jan sprak met [twee moeders [van elk drie kinderen]] Jan spoke with two mothers of each three children

b. ${ }^{*}$ Jan sprak met [elk twee moeders [van drie kinderen]] Jan spoke with each two mothers of three children

Finally, just like in the clausal domain (Burzio 1986; Safir \& Stowell 1988: 446), the antecedent (Range-NP) should not be too far away from the Dist-NP. In other words, a locality constraint applies to the dependency relation.

(25) a. Jan toonde mij $\left[_{D P}\right.$ een foto van $[D P$ twee halters van elk 75 kilo]] Jan showed me a picture of two dumbbells of each 75 kilo

b. ${ }^{*} J a n$ toonde mij [DP twee foto's van $\left[_{D P}\right.$ een halter van elk 75 kilo]] Jan showed me two pictures of a dumbbell of each 75 kilo

Summarizing, I have tried to show in this section that the (noun phrase internal) dependency relation between binominal elk and its antecedent (the Range-NP) displays the grammatical properties that are characteristic of the dependency relation between a bound anaphor and its antecedent. 


\section{More instances of the DP-internal binominal pattern}

In my discussion so far I have concentrated on the Dutch quantifier elk. As for the syntax of this binominal quantifier, two major structural analyses can be found in the literature. First of all, Safir \& Stowell (1988) propose binominal each projects a QP (i.e. phrasal constituent) that is right-adjoined to Dist-NP (see (26)). They further propose that each selects an anaphoric empty category (coindexed with the Dist-NP) as its complement, and a PRO (coindexed with the Range-NP) as its specifier. The anaphoric empty category $\left(e_{j}\right)$ must be licensed by the Range-NP in a local configuration (involving c-command) at LF. For the exact analysis, I refer the reader to Safir and Stowell's article.

(26) $\int_{I P}$ The kids ${ }_{j}\left[_{V P}\right.$ bought $\left[_{N P}\left[_{N P} \text { three books }\right]_{i}\left[_{Q P} P R O_{i}\left[_{N}\right.\right.\right.$, each $\left.\left.\left.\left.\left.e_{j}\right]\right]\right]\right]\right]$

Zimmermann (2002) proposes a different structural analysis (see (27)). According to him, binominal each is a nominal projection embedded within a PP. So, also in his analysis the constituent representing the distributing element is phrasal. The head of this PP can sometimes be empty. Just like in Safir \& Stowell's analysis, there is a local restricting NP-complement for the universal quantifier inside the DP. This restriction can surface overtly (e.g. weil in German jeweils; see (7) or covertly ( $\varnothing$, as in English each). The restriction receives its value through co-indexation with the Range-NP antecedent.

(27) $I_{I P}$ The kids $\left[_{j}\left[_{V P}\right.\right.$ bought $\left[_{D P} D\left[_{N P}\right.\right.$ three books $]\left[_{P P} P_{\varnothing}\left[{ }_{Q P}\right.\right.$ each $\left.\left.\left.\left.\left.\left[_{N P} e_{j}\right]\right]\right]\right]\right]\right]$

Although a full-fledged analysis of the precise syntactic structure of the Dist-XP falls beyond the scope of this article, I would like to make a few observations on the basis of a richer set of Dutch data involving binominal readings (all examples are drawn from the internet via a Google-search). Besides showing that there is a large variety of instantiations of the binominal pattern, these examples confirm what Safir \& Stowell (1988) and Zimmermann (2002) have already observed: (a) the distributing element is phrasal (XP), and (b) the anaphoric element that enters into a dependency relation with the Range-NP (the antecedent) can be overt or covert. An observation that can be added to this is that besides binominal patterns involving a distributive reading we also find patterns involving a collective reading (i.e. the thing/property designated by the nominal expression following van applies to the entire set (group/aggregate/total sum) corresponding to 'cardinal+NP').

(28) a. onder oplegging van twee dwangsommen van ieder afzonderlijk $€ 1.500$ per week

under enforcement of two penalty-payments of each separate $€ 1.500$ per week 
b. vier kippenbouten van per stuk 200 gram four chicken-legs of per piece 200 gram

(29) a. twee groepen van bij elkaar zo'n 60 bezoekers two groups of with each-other approximately 60 visitors

b. na [een vlucht van alles bij elkaar 11 minuten] after a flight of all with together 11 minutes

(30) a. twee boeken van samen/tezamen 1600 pagina's two books of together/together 1600 pages

b. Het waren [zeven gesprekken van alles samen acht en een half uur]. it were seven conversations of all together eight and a half hour

(31) a. na twee zittingsdagen van opgeteld/samengenomen bijna zestien uur after two sessions of up-added/together-taken almost sixteen hours

b. twee gewichten van als je ze optelt/samenneemt nog geen honderd kilo two weights of when you them up-add together-take yet no hundred kilo

That the binominal element can be phrasal is clearly shown by examples like (28), (29), (30b), and (31b). The examples (29)-(31) exemplify the existence of a pattern involving a collective reading rather than a distributive reading ((28)). The examples in (28)-(31) further show that there are different categorial manifestations of Dist-XP/Coll-XP, such as PP (e.g. (28b), (29a)), VP/CP (31)). Finally, some of the examples clearly show an overt anaphoric element that enters into a dependency relation with the range-NP (e.g. elkaar in (29) and ze in (31b)). It does not seem unlikely that there is an empty pro-form present in those patterns that do not feature an overt pronominal element. For example, in view of the thematic properties of the participles in (31a) - that is, they select a theme-argument - it does not seem implausible that there is a covert pro-form present in these phrases. On the basis of the above observations I come to the following schematic structure:

$$
\left[{ }_{\mathrm{DP}} \text { cardinal }+\mathrm{NP}\left[{ }_{\mathrm{PP}} \operatorname{van}\left[\left[_{\mathrm{XP}} . \text { pro-form.. }\right] \mathrm{NP}\right]\right]\right]
$$

Let me finally point out that, modulo the cardinality requirement, the pattern in (32) is also realized by the examples in (33), where an AP (a secondary predicate) enters into a dependency relation with a DP-internal antecedent. Arguably, this dependency is established by coindexation of the antecedent and the empty theme-argument of the adjective (say, [pro los]).

(33) a. Vroeger had ik [een atletisch lichaam van schoon aan de haak $90 \mathrm{~kg}$ ]. formerly had I an athletic body of clean on the hook $90 \mathrm{~kg}$

b. Het is [een toestel van los bijna 600 euro en met abbo rond de 1000 euro]. it is a phone of separate nearly 600 euro and with abbo around the 1000 euro 


\section{Word order rearrangements}

In the Dutch examples discussed so far, the adnominal XP containing the proform (see (32)) typically precedes the Dis-NP (or the Coll-NP for that matter). Zimmermann (2002) observes that in certain languages the adnominal XP can both precede and follow the Dist-NP. For example, German jeweils (see (7)) can occur in prenominal (34a) and postnominal (34b) position:

(34) a. [Drei Würstchen jeweils] haben die Jungen gegessen. three sausages each have the boys eaten

b. [Jeweils drei Würstchen] haben die Jungen gegessen.

As shown in (35), Dutch also permits the postnominal occurrence of the distributing/collecting element.

(35) a. Jed haalde [twee munten van dertig gram elk] uit zijn rugzak. Jed took two coins of thirty gram each out-of his backpack

b. vier kippenbouten van [400 gram per stuk] four chicken-legs of 400 gram per piece

c. 29,95 voor twee halterschijven van [20 kg samen] 29,95 for two dumbbells of $20 \mathrm{~kg}$ together

d. twee groepen van [zo'n 60 bezoekers bij elkaar opgeteld] two groups of such-a 60 visitors with each-other up-added

e. Soepkippen van [1 $\mathrm{kg}$ schoon aan de haak] bestaan dus niet. soup-chickens of $1 \mathrm{~kg}$ clean on the hook exist thus not

f. twee gewichten van [nog geen 100 kilo als je ze optelt] two weights of yet no 100 kilo if you them up-add

Following Lipták \& Zimmermann (2000) and Zimmermann (2002: 111 ff.), I propose that the postnominal position (see (36a)) is the base-generated position and that the prenominal position is a movement-derived position (see (36b)). More specifically, I will follow their suggestion that the adnominal XP is moved to Spec,DP for discourse-related reasons. It is the topical status of XP, which is arguably due to the overt/covert pro-form that is coindexed with the DP-internal antecedent, that triggers Topic Fronting to Spec,DP. If some other element within the DP is more discourse-prominent, for example due to focalization, the adnominal position stays in its postnominal base position.

(36) a. $\left[_{\mathrm{DP}}\right.$ cardinal $+\mathrm{NP}\left[_{\mathrm{PP}}\right.$ van $\left[_{\mathrm{DP}} \operatorname{Spec}\left[_{\mathrm{D}}, \mathrm{D}\left[_{\mathrm{NumP}} \mathrm{NumP}\left[_{\mathrm{XP}}\right.\right.\right.\right.$ ..pro-form..]]]]]]

b. $\quad\left[_{D P}\right.$ cardinal + NP $\left[{ }_{P P}\right.$ van $\left[{ }_{D P}\left[{ }_{X P} . \text { pro-form.. }\right]_{i}\left[{ }_{D}, D\left[_{N u m P}\right.\right.\right.$ NumP $\left.\left.\left.\left.\left.t_{i}\right]\right]\right]\right]\right]$ 
A potential argument in support of the movement analysis in (36b) comes from nominal expressions featuring more than one XP that can potentially occur in the left periphery of DP. Consider first (37a), where the distributing PP per stuk and the secondary predicate schoon aan de haak both follow the Dist-NP $1 \mathrm{~kg}$. $(37 \mathrm{~b}, \mathrm{c})$ show that both per stuk and schoon aan de haak can occur to the left of $1 \mathrm{~kg}$. As shown by $(37 \mathrm{~d}, \mathrm{e})$, it is impossible to have the two XPs in a position preceding $1 \mathrm{~kg}$. This would follow from an analysis like (36b), in which there is only one landing site (viz. Spec,DP) available for the fronted XP. ${ }^{1}$

(37) a. twee soepkippen van [1 kg [per stuk] [schoon aan de haak]] two soupchickens of $1 \mathrm{~kg}$ per piece clean on the hook

b. twee soepkippen van [per stuk $1 \mathrm{~kg}$ schoon aan de haak]

c. twee soepkippen van [schoon aan de haak $1 \mathrm{~kg}$ per stuk]

d. ${ }^{*}$ twee soepkippen van [per stuk schoon aan de haak $1 \mathrm{~kg}$ ]

e. ${ }^{*}$ twee soepkippen van [schoon aan de haak per stuk $1 \mathrm{~kg}$ ]

\section{Conclusion}

In this article I have examined nominal expressions featuring a quantifier that is floating in the sense that it is separate from (non-adjacent to) its antecedent. I have shown that this quantifier exhibits the grammatical behavior that is characteristic of so-called 'binominal each'. This means that dependencies involving binominal each are attested both in the clausal domain (CP) and in the nominal domain (DP). In other words, clausal and nominal expressions behave symmetrically as regards the 'binominal each' phenomenon.

\section{Note}

1. A reviewer of this article finds example (37e) quite acceptable if we have elk instead of per stuk. A more systematic investigation of these patterns featuring two XPs is obviously needed. I leave this for future research.

\section{References}

Bennis, Hans. 1986. Gaps and dummies. Dordrecht: Foris Publications.

Blaheta, Don. 2003. Binominal each: Evidence for a modified type system. MA thesis, Brown University, Providence Rhode Island. 
Bobaljik, Jonathan. 2003. Floating quantifiers: Handle with care. In Lisa Cheng \& Rint Sybesma (eds.), The Second Glot International State-of-the-Article Book, 107-148. Berlin: Mouton de Gruyter.

Burzio, Luigi. 1986. Italian syntax. Dordrecht: Reidel. DOI: 10.1007/978-94-009-4522-7

Cirillo, Robert. 2009. The syntax of floating quantifiers. PhD dissertation, University of Amsterdam. Utrecht: LOT.

Doetjes, Jenny. 1997. Quantifiers and selection. PhD dissertation, Leiden University (Hill-diss 32). Dordrecht : ICG-printing.

Kayne, Richard. 1994. The antisymmetry of syntax. Cambridge, MA: MIT Press.

Lipták, Aniko \& Malte Zimmermann. 2000. A unified analysis of binominal each-constructions in English, Dutch and German. SKY Journal of Linguistics 13.

Safir, Ken \& Tim Stowell. 1988. Binominal each. In James Blevins \& Juli Carter (eds.), Proceedings of NELS 18, 426-450. Amherst: GLSA Publications.

Sportiche, Dominique. 1988. A theory of floating quantifiers and its corollaries for constituent structure. Linguistic Inquiry 19. 425-449.

Zimmermann, Malte. 2002. Boys buying two sausages each - On the syntax and semantics of distance distributivity. $\mathrm{PhD}$ dissertation, University of Amsterdam. Utrecht: LOT.

\section{Author's address}

Norbert Corver

Utrecht Institute of Linguistics OTS

Trans 10

3512 JK Utrecht, The Netherlands

N.F.M.Corver@uu.nl 